Tropical Journal of Pharmaceutical Research December 2012; 11 (6): 1013-1021

(c) Pharmacotherapy Group,

Faculty of Pharmacy, University of Benin, Benin City, 300001 Nigeria.

All rights reserved.

Available online at http://www.tjpr.org

Review Article

http://dx.doi.org/10.4314/tjpr.v11i6.19

\title{
Pharmaceutical Approaches and Advancements in Male Contraception
}

\section{Evren Algın Yapar $^{1 *}$ and Özge İnal ${ }^{2}$}

${ }^{1}$ Ministry of Health of Turkey, Turkish Medicines and Medical Devices Agency Söğütözü Mah. 2176. Sok. No:5 Kat:6, 06520 Çankaya-Ankara, ${ }^{2}$ Department of Pharmaceutical Technology, Faculty of Pharmacy, University of Ankara, 06100 Tandoğan- Ankara, Turkey

\begin{abstract}
Currently available contraceptive methods offer a variety of options for women, but only very few for men which include surgical methods, condom and hormonal methods. Non-surgical and non-hormonal methods are under investigation. Among these, hormonal contraceptive approaches, including injections, oral and transdermal delivery systems of testosterone, have attracted the attention of investigators. Also non-hormonal approaches based on chemicals extracted from different plants such as cotton seed plant, Neem tree, Trypterigium wilfordii and Momordica Charantia seed, are known to have effect on male fertility. Additionally, alkylated imino sugars, $\mathrm{Ca}^{++}$channel blockers, indenopyridines, indazole-3-carboxylic acid analogues, reversible inhibition of sperm under guidance (RISUG) which involves injection of stericmaleic anhydride with dimethyl sulfoxide, spermicidemicrobicide (including gel formulations) and vaccine approaches are intended to interfere in a certain fertilization step. Information obtained from multi-center studies in several countries on both men or women shows the necessity for additional reversible male contraceptive methods. Results from recent surveys clearly indicate that there is a market and a need for novel pharmaceutical preparations for male contraception.
\end{abstract}

Keywords: Male Contraception, Contraceptive agents, Hormonal methods 


\section{INTRODUCTION}

Recent available contraceptive methods offer a variety of options for women, but only very few (condom and sterilization) for men. The choice of method either for women or men depends very much on the cultural background of the user-groups. It has been observed that, world-wide, approximately 20 - $30 \%$ of couples using contraceptives employ a male method, and the only available reversible male methods are condom and vasectomy [1-3]. Recent surveys indicate that approximately $90 \%$ of partners tend to be active in choosing a suitable contraception method, and more than $50 \%$ of men want to take responsibility [3]. The socio-economic status and religion of couples, as well as government policies and actions influence the type and usage of contraception in a country. Men's age and level of education have been found to have a significant influence on the acceptance of contraceptive methods in developing countries [4].

Information obtained from multi-center studies in different societies will be useful in the design of future products and introduction of a near ideal method. For example, when men attending a multi-center study were asked to rank condoms, a daily pill, a threemonthly injection and long-term implant, men from Edinburgh showed preference for a male pill, and an implant was the least prevalent first choice. By contrast, an implant was the second favored choice, and a pill the least favored among men from Shanghai [1,5]. Among women involved in a multicenter survey performed in the United Kingdom, South Africa and China, over $65 \%$ agreed that the responsibility for contraception falls too heavily on women while over $71 \%$ felt that developing a "male pill" would be a good idea [6]. Additionally, various opinion polls have shown a generally high acceptance rate of a potential hormonal male contraceptive by men as well as women [7]. Generally, results from recent surveys clearly implicate that there is a market and a need for a novel male contraceptive method [5-8].

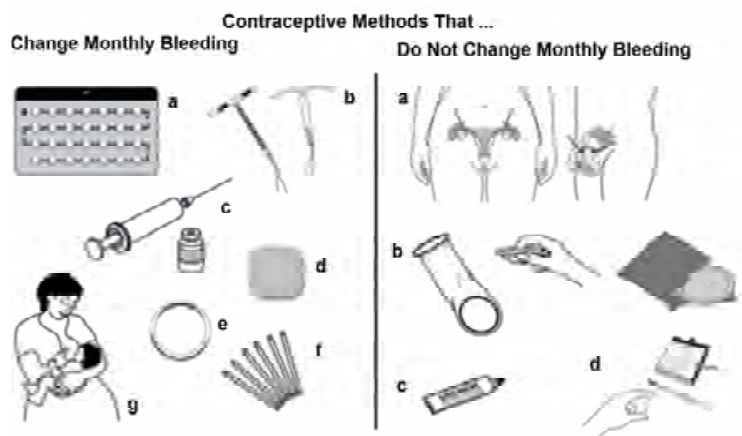

Fig. 1: Illustration of contraceptive methods. Left side: a) Combined and progestin-only contraceptives, b) copper and hormonal IUDs, c) injectables d) patch, e) vaginal ring, f) implant (these all alter monthly bleeding to varying degrees), and g) lactational amenorrhea method (LAM)-breastfeeding in a way that reliably postpones the return of fertility. Right side, a) Female and male sterilization, b) barrier methods (female condom and diaphragm, male condom), c) spermicides, and d) fertility awareness-based methods do not change monthly bleeding [9] .

Currently available methods presented in Figure 1 [9] can be summarized as surgical methods, condom, hormonal methods, nonsurgical and non-hormonal methods [1,3]. Hormonal contraceptive approaches try to induce suppression of spermatogenesis or bring about azoospermia by suppressing the gonadotrophins and thereby eliminating intratesticular testosterone (T) through the use of $T$ alone or in combination with gestagens as a standard regimen [10]. Strategies investigated for $\mathrm{T}$ administrations include injections, oral or transdermal delivery systems at weekly or longer intervals [10-13].

Non-hormonal approaches for men tend to hinder sperm function and maturation $[8,10]$. These approaches have been carried out using chemicals such as gossypol extracted from cotton seed plant (Gossypium sp.) and triptolide extracted from Trypterigium wilfordii; these were promising non-hormonal agents 
in the 1980s and 1990s in China [8,14-16]. Also, the Asian tree, Neem (Azadirachta indica) and the methanol extract of Momordica Charantia seed, are known to have an effect on male fertility $[2,17]$.

Non-hormonal approaches have a number of potential advantages over hormonal methods, such as rapidity of onset and lack of interference with non-reproductive androgen-dependent function. However, the azoospermia effect of gossypium was found to be irreversible in $20 \%$ of men who had taken it for prolonged periods [8]. Additionally, alkylated imino sugars [18], $\mathrm{Ca}^{++}$ channel blockers [19-20], indenopyridines $[16,20,21]$, indazole-3-carboxylic acid analogues $[10,20]$, reversible inhibition of sperm under guidance (RISUG) which involves injection of stericmaleic anhydride (SMA) combined with dimethyl sulfoxide (DMSO) $\quad[1,16,20,22], \quad$ spermicidemicrobicide (including gel formulations) [23] and vaccine approaches $[1,16,20,24]$ are intended to interfere in a specific fertilization step [1,25]. These non-hormonal methods include attempts to decrease sperm production or motility or to block the ability of sperm to fertilize the ovum $[10,16]$.

Vaccine approaches involves the use of antigens/antibodies to target different aspects of gamete production and function as a means of inducing infertility $[8,26-29]$. For example, vaccines based on luteinizing hormone-releasing hormone/gonadotropin releasing hormone $(\mathrm{GnRH})$ have been tested, and they have been shown to affect testosterone production, resulting in decrease in testis and prostate weights $[30,31]$.

Researchers have attached more importance to hormonal methods which require the administration of exogenous $T$ combined with a progestogen to suppress the secretion of luteinizing hormone (LH) and folliclestimulating hormone (FSH) from the pituitary gland $[10,32]$. Most early studies have used $\mathrm{T}$ alone because of the expediency that gonadotrophin suppression and androgen replacement can be achieved with a single agent. However, oral bioavailability of unmodified $T$ is poor because of hepatic firstpass metabolism and orally active 17alkylated $T$ analogues are hepatotoxic. The daily physiological requirement of $T$ in men can only be achieved with depot preparations of injectable T esters or implantable T pellets $[8,16,33]$.

To deliver $\mathrm{T}$, most male hormonal contraceptive regimens have relied on injectable or implantable formulations of $T$. However, the relatively frequent injections required to maintain serum $\mathrm{T}$ levels necessitate frequent clinic visits and can be painful [34-36].

Because of the shortcomings of currently available methods of male contraception, efforts have been made to develop additional forms of contraception for men. Recent trials with newer, long-acting forms of injectable $T$, which can be administered every 8 weeks, combined with progestogens, administered either orally or by long-acting implant, have yielded promising results and may soon result in the marketing of a safe, reversible, and effective hormonal contraceptive for men [37-39].

At this point, an ideal male hormonal contraceptive should meet some of the features highlighted in Table 1 [40];

Table 1: Features of an ideal male-directed (hormonal) contraceptive [40]

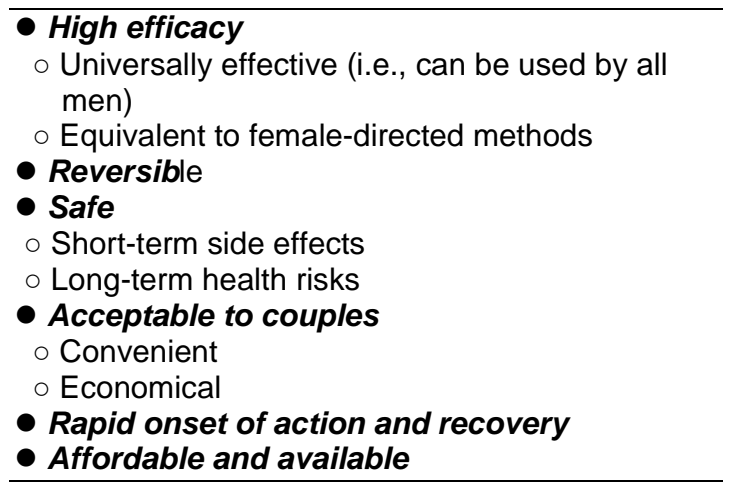

Trop J Pharm Res, December 2012;11 (6):1015 
The mechanism of action of hormonal contraceptives is presented in Figure 2 [41] , and hormonal contraceptive regimes can be summarized under three headings [32];
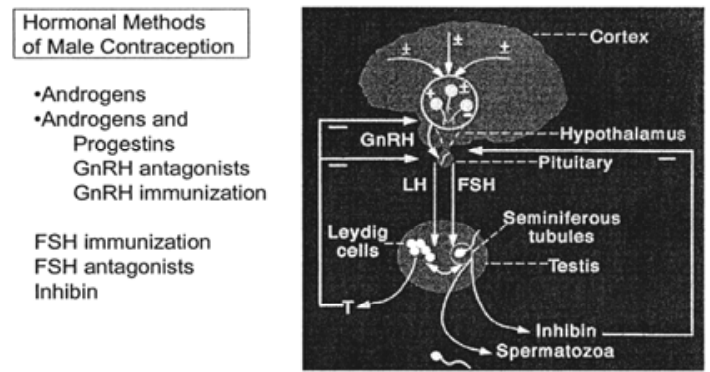

Fig 2: The hypothalamic-pituitary-testis axis showing the negative feedback of gonadal steroids and inhibin on $\mathrm{GnRH}$, FSH, or $\mathrm{LH}$ secretion. The hormonal method of male contraception works by inhibition of secretion of both FSH and LH [41].

\section{Androgen only}

Due to poor oral bioavailability of unmodified $\mathrm{T}$ and hepatotoxicty of orally active 17alkylated $\mathrm{T}$ analogues, daily physiological requirement for milligram amounts of $T$ in men can be achieved with injectable depot preparations or transdermal formulations of $\mathrm{T}$ esters or implantable pellets containing crystalline $\mathrm{T}[33,42,43]$.

Testosterone undecanoate (TU) is an unsaturated ester of $T$ with a long hydrophobic aliphatic fatty acid side chain which renders it highly fat-soluble. Formulation of TU in tea seed oil $(125 \mathrm{mg} / \mathrm{ml})$ and castor oil (Nebido ${ }^{\mathrm{TM}} 250 \mathrm{mg} / \mathrm{ml}$ ) yielded long-acting depot preparations for intramuscular use. TU (in castor oil) has a long half-life of 70 days with more stable pharmacokinetics when administered at 4-8 weekly intervals. TU (in tea seed oil) $500 \mathrm{mg}$ monthly i.m. can induce azoospermia or oligozoospermia (<3 million/ml) in $97 \%$ of Chinese subjects with high contraceptive efficacy (one pregnancy in 143 person years exposure, i.e., a failure rate of $2.3(95 \% \mathrm{Cl}$ 0.5 - 4.2) per 100 couple-years) [33,44]. These encouraging results are being followed-up by phase 3 studies involving
$>1000$ men in 10 centers in China where a new and more concentrated formulation of TU in soybean oil $(250 \mathrm{mg} / \mathrm{ml})$ is also under investigation [33].

Scrotal transdermal $\mathrm{T}$ patches were introduced in the late 1980s [16]. Several novel transdermal delivery systems (patches and gels) of $\mathrm{T}$ have become available recently. While self-administration and maintenance of physiological $\mathrm{T}$ blood levels offer obvious convenience and advantages in androgen replacement for hypogonadism, the requirement for daily application and higher levels of variability in skin absorption raises an important issue of compliance, not to mention the high incidence of skin irritation with the reservoir patch. Unsurprisingly, transdermal $\mathrm{T}$ on its own has not been investigated as a potential contraceptive formulation $[10,16,33]$.

7a-Methyl-19-nortestosterone (MENT) is a highly potent synthetic androgen which is resistant to 5-reductase but sensitive to aromatase. In a preliminary dose-finding study, four sub-dermal MENT acetate implants (each delivering $400 \mu \mathrm{g} /$ day) have been shown to suppress gonadotrophins and induce azoospermia in $64 \%$ of men with a suggestion of reduction in prostate volume by $10-17 \%$ after 6 months $[33,45]$.

\section{Progestin/androgen combinations}

Exogenous progestins can inhibit gonadotrophin secretion in men, and suppress spermatogenesis. Combining a progestin with androgens for male contraception exploits the synergistic actions of the two steroids so that they can be used at lower doses thus minimizing the potential for side effects $[8,33]$.

It has been reviewed that, depot medroxyprogesterone acetate (DMPA) has an azoospermia effect in approximately $50 \%$ of men, according to WHO [8]. DMPA has been combined with 19-nortestosterone (19NT), Testosterone enanthate (TE) and T 
implants. Studies with 19-NT and TE in combination with DMPA in Indonesian men indicate azoospermia rates of $98 \%[8,33]$. A male contraceptive study has been performed using daily self-administration of T-gel in combination with injections of DMPA every 3 months in normal men [46]. This study demonstrated that the improved $\mathrm{T}$ delivery of the gel results in sperm suppression similar to that achieved with frequent injections of intramuscular $T$ combined with a progestogen $[46,47]$.

While the addition of an androgenic progestin to $T$ is a rational choice, the use of an antiandrogenic progestin without $T$ appears not quite logical. An attempt to create a male pill by co-administration of oral TU with an orally active antiandrogen and progestogen cyproterone acetate (CPA) led to suppression of spermatogenesis, but had to be discontinued due to an antiandrogen-caused decrease in hemoglobin and hematocrit $[8,16,48]$.

CPA combines anti-gonadotrophic and antiandrogenic properties which may be particularly favorable for suppression of spermatogenesis, especially in high doses (200 mg/day) [8]. Oral CPA at doses of $25-$ $100 \mathrm{mg} /$ day combined with TE $100 \mathrm{mg} / \mathrm{week}$ resulted in rapid onset of azoospermia in the subjects, whereas the same dose of TE alone was less effective $[8,16,33,49]$.

Testosterone patches have been combined with oral levonorgestrel (LNG, $125 \mathrm{~g}$ daily) and long-acting LNG implants (four rods, Norplant II). Relatively poor sperm suppression (severe oligozoospermia in $<60$ $\%)$ probably relates to the unreliable administration or absorption of $\mathrm{T}$ so that circulating levels in the low normal range only can be achieved $[8,33]$.

However, when LNG was administered in four capsules delivering about $160 \mathrm{~g}$ LNG (Norplant II,Jadelle) per day together with weekly injections of $100 \mathrm{mg} \mathrm{TE}, 93 \%$ of the subjects achieved azoospermia and all suppressed oligozoospermia to $<1 \times 10^{6}$ sperm $/ \mathrm{ml}$. Long-acting LNG implants (four rods of Norplant II) combined with injectable TE were significantly more effective than LNG (125 $\mu \mathrm{g}$ daily) combined with T patches [50]. As effective as this combination may be, it brings us back to weekly $T$ injections, making the approach impractical for general use. The combination of levonorgestrel implants with long-acting testosterone preparations (ideally also implants) might be a solution and requires investigation [51].

Desogestrel (DSG) is an oral third generation synthetic progestin with potent progestational activity but lower androgenicity. These potentially favourable properties led to the study of desogestrel in combination with TE. A cross-national study confirmed that oral DSG (150 or $300 \mathrm{~g}$ daily) in combination with injectable TE or $400 \mathrm{mg}$ T pellets (every 12 weeks) can induce azoospermia in virtually all men in the $300 \mathrm{~g}$ group with a significant decline in HDL-C in Caucasian men only $[15,32,51]$. Further study of this promising progestin implant in combination with TU injections is in progress.

Norethisterone (NET) is an androgenic progestin which can be delivered as NET enanthate (NETE), an i.m. aqueous depot preparation available in Europe for female contraception. NETE $400 \mathrm{mg}$ and TU 1000 $\mathrm{mg}$ administered at 6-weekly intervals induced azoospermia in $92 \%$ of men. In another study, men who received the combination of $1000 \mathrm{mg}$ TU and $200 \mathrm{mg}$ NET for every 6 week achieved azoospermia after 32 weeks of treatment. It was demonstrated that high rates of azoospermia (90\%) can be maintained when TU and NETE are administered for 8 weeks intervals, but not for dosed every 12 weeks. This promising regime consisting of two long-acting depot injectable preparations is being further investigated in planned multi-centre studies $[8,11,16]$.

A buccal dosage unit is provided for administering a contraceptive composition to 
fertile mammalian males has been granted a patent in 2001. The buccal dosage unit comprises an androgenic agent (testosterone or ester forms of testosterone) and a progestin in a polymeric carrier that bioerodes and provides for delivery of the active agents throughout a predetermined drug delivery period that is preferably in the range of approximately 8 to 24 h [53].

Currently injectable $\mathrm{T}$ combined with gestagens or administered as implants are being tested for possible licensing. Although scrotal and non-scrotal $\mathrm{T}$ patches, orally administered TU and $\mathrm{T}$ gels are generally well tolerated and provide stable $\mathrm{T}$ levels in the normal range, their use showed generally disappointing efficacy due to insufficient gonadotropin suppression. Further large multi-centre studies are required to establish the contraceptive efficacy of the most promising steroid combinations [54].

The latest progestin to be tested for male contraceptive purposes is the orally effective dienogest. As dienogest has only mild antiandrogenic activity, this substance may be a possible candidate for future trials [51].

\section{GnRH antagonists}

$\mathrm{GnRH}$ antagonists are competitive blockers of $\mathrm{GnRH}$ receptor binding and suppress gonadotrophins within $24 \mathrm{~h}$. Studies have shown very rapid spermatogenic suppression with a high rate of azoospermia. Whilst these complex synthetic peptides clearly have contraceptive potential (main advantage is being faster suppression than sex steroids), they have disadvantages like high cost, short half-life and the need for frequent subcutaneous injection. New long-acting depot preparations of potent $\mathrm{GnRH}$ antagonists may, therefore, have a place in male contraception where rapid induction of spermatogenic suppression can subsequently be maintained by testosterone with or without progestins [33].
$\mathrm{GnRH}$ antagonists in combination with testosterone lead to a more rapid onset and complete suppression of sperm [55], but the preparations currently available require daily or weekly injections and are expensive [51]. $\mathrm{GnRH}$ antagonist Nal-Glu, administered by daily subcutaneous injection, in combination with $\mathrm{T}$ is one of the trials on $\mathrm{GnRH}$ analogs. In the initial studies with Nal-Glu, after two weeks of administration, azoospermia was induced in 14 of 16 men $[8,16]$.

A literature search by Hoesl et al [56] provides strong support for the male contraception approach. Their findings, presented as a cross-cultural survey, show men's willingness to bearcontraceptive responsibility. Clinical trials substantiate that hormonal contraception involving suppression of gonadotropins holds the best promise to provide a male pharmacological contraceptive. Androgens have been demonstrated to induce reversible infertility particularly in combination with certain progestins and $\mathrm{GnRH}$ antagonists. Advances in non-endocrine contraception include intervention with triptolide derivatives, alkylated imino sugars, and immunization by eppin. With respect to pharmacology, the male contraceptive has been considerably advanced in recent years. Long-term studies involving a greater number of subjects may result in a safe, reversible and effective means. Asia is likely to be the first market for male hormonal contraceptive methods. The clinical evaluation of non-endocrine approaches may ultimately lead to an alternative to hormone-based male contraception.

Hormonal methods are closer to becoming an available method compared to non-hormonal methods. However, the combination of two hormones, requiring also two modes of delivery, is complex and might not appear attractive to users [10]. Further research is needed to assess the long-term safety, continuation rates, satisfaction among users and issues related to service delivery [35]. An intensive search for a second-generation of

Trop J Pharm Res, December 2012;11 (6):1018 
male contraceptive drugs is ongoing, supported by several organizations such as World Health Organization (WHO), National Institutes of Health $(\mathrm{NIH})$, Contraceptive Research and Development Program (CONRAD), the Population Council and several other medical research councils $[10,57]$.

\section{CONCLUSION}

The drawback of surgical approaches (such as vasectomy) especially patient compliance and the low success rates with condoms has spurred research on hormonal contraceptive dosage forms. There is a dearth of investigations in the development of pharmaceutical preparations. Evolving technology in the 21st century as well as improvement in living standards further underline the need for new male contraception approaches, especially those that entail new drug delivery methods.

\section{REFERENCES}

1. Lye RJ, Sipilä $P$, Vernet $P$, Wagenfeld $A$. Male contraception-a topic with many facets. Molecular and Cellular Endocrinology 2004; 216: 75-82.

2. Yama OE, Osinubi AA, Duru FIO, Noronha CC, Okanlawon AO. Contraceptive effect of methanolic extract of Momordica Charantia seed in male sprague-dawley rats. Asian $J$ Clinical Pharmaceutical Research 2011; 4(2): 22-26.

3. Naz RK, Rowan S. Erkek kontrasepsiyonunda güncel yaklaşımlar. [Update on male contraception.] Current Opinion Obstet Gynnecol, Turkish Edition. 2009; 21: 265-269.

4. Drennan M. Reproductive health: new perspectives on men's participation. Population Reports 1998; J(46).

5. Martin CW, Anderson RA, Cheng L, Ho PC, van der Spuy $Z$, Smith $K B$, Glasier $A F$, Everington $D$, Baird DT. Potential impact of hormonal male contraception: cross-cultural implications for development of novel preparations. Hum Reprod 2000; 15(3): 637-645.

6. Glasier $A F$, Anakwe $R$, Everington D, Martin $C W$, van der Spuy Z, Cheng L, Ho PC, Anderson $R A$. Would women trust their partners to use a male pill? Hum Reprod 2000; 15(3): 646-649.

7. Nieschlag E. The struggle for male hormonal contraception. Best Practice Res Clin Endrocrin Metabol 2011; 25: 369-375.
8. Anderson RA, Baird DT. Male contraception. Endocr Rev 2002; 23(6): 735-762.

9. Meyer R, Mueller F, Beisser M. Johns Hopkins' CCP. When Contraceptives Change Monthly Bleeding. Series J, Number 54, Family Planning Programs. [Homepage on the Internet] http://www.k4health.org/pr/j54/1.shtml Accessed 21. February, 2012

10. Sitruk-Ware $R$. Delivery options for contraceptives. DDT 2005; 10(14): 977-985.

11. Kamischke $A$, Heuermann $T$, Kruger $K$, von Eckardstein S, Schellschmidt I, Rubig A, Nieschlag $E$. An effective hormonal male contraceptive using testosterone undecanoate with oral or injectable norethisterone preparations. J Clin Endocrinol Metab 2002; 87(2): 530-539.

12. Meriggiola MC, Bremner WJ, Costantino A, Di Cintio G, Flamigni C. Low dose of cyproterone acetate and testosterone enanthate for contraception in men. Hum Reprod 1998; 13(5): 1225-1229.

13. Wu FC, Balasubramanian $R$, Mulders TM, Coelingh-Bennink HJ. Oral progestogen combined with testosterone as a potential male contraceptive: additive effects between desogestrel and testosterone enanthate in suppression of spermatogenesis, pituitarytesticular axis, and lipid metabolism. J Clin Endocrinol Metab 1999; 84(1): 112-122.

14. Waites GM, Wang C, Griffin PD. Gossypol: reasons for its failure to be accepted as a safe, reversible male antifertility drug. Int $J$ Androl 1998; 21(1): 8-12.

15. Huynh PN, Hikim APS, Wang C, Stefonovic K, Lue $Y H$, Leung $A$, Atienza $V$, Baravarian $S$ Reutrakul V, Swerdloff RS. Long-term effects of triptolide on spermatogenesis, epididymal sperm function, and fertility in male rats. $J$ Androl 2000; 21(5): 689-699.

16. Page ST, Amory JK, Bremner WJ. Advances in male contraception. Endocrin Rev Metab 2008; 29(4): 465-493.

17. Upadhyay SN, Dhawan S, Talwar GP. Antifertility effects of neem (Azadirachta indica) oil in male rats by single intra-vas administration: an alternate approach to vasectomy. J Androl 1993; 14(4): 275-281.

18. Van der Spoel $A C$, Jeyakumar $M$, Butters $T D$, Charlton HM, Moore HD, Dwek RA, Platt FM. Reversible infertility in male mice after oral administration of alkylated imino sugars: a nonhormonal approach to male contraception. Proc Natl Acad Sci USA 2002; 99: 1717317178.

19. Darszon A, Lopez-Martinez $P$, Acevedo $\mathrm{JJ}$, Hernandez-Cruz A, Trevino CL. T-type $\mathrm{Ca}^{2+}$ channels in sperm function. Cell Calcium 2006; 40(2): 241-252.

Trop J Pharm Res, December 2012;11 (6):1019 
20. Cheng $C Y$, Mruk $D D$. New frontiers in nonhormonal male contraception. Contraception 2010; 82: 476-482.

21. Hild SA, Attardi BJ, Reel JR. The ability of a gonadotropin-releasing hormone antagonist, acyline, to prevent irreversible infertility induced by the indenopyridine, CDB-4022, in adult male rats: the role of testosterone. Biol Reprod 2004; 71: 348-358.

22. Lohiya NK, Suthar R, Khandelwal A, Goyal S, Ansari AS, Manivannan B. Sperm characteristics and teratology in rats following vas deferens occlusion with RISUG and its reversal. Int J Androl 2010; 33: 198-206. (doi:10.1111/j.1365-2605.2009.00992.x.)

23. Anderson DJ, Williams DL, Ballagh SA, Barnhart $K$, Creinin MD, Newman DR, Bowman FP, Politch $J A$, Duerr AC, Jamieson DJ. Safety analysis of the diaphragm in combination with lubricant or acidifying microbicide gels: effects on markers of inflammation and innate immunity in cervicovaginal fluid. Am J Reprod Immunol 2009; 61: 121-129.

24. Jensen JT. Male contraception. Current Women's Health Reports 2002; 2(5): 338-345.

25. Burkman $R$, Bell $C$, Serfaty $D$. The evolution of combined oral contraception: improving the risk-to-benefit ratio. Contraception 2011; 84(1): 19-34.

26. Naz RK, Gupta SK, Gupta JC, Vyas HK, Talwar GP. Recent advances in contraceptive vaccine development: a mini-review. Hum Reprod 2005; 20(12): 3271-3283.

27. Aitken RJ. Immunocontraceptive vaccines for human use. J Reprod Immunol 2002; 57: 273287.

28. Frayne $J$, Hall $L$. The potential use of sperm antigens as targets for immunocontraception; past, present and future. J Reprod Immunol 1999; 43: 1-33.

29. Suri A. Family of sperm associated antigens: relevance in sperm-egg interaction and immunocontraception. Soc Reprod Fertil Suppl 2007; 63: 433-443.

30. Simms MS, Scholfield DP, Jacobs $E$, Michaeli $D$, Broome P, Humpreys JE, Bishop MC. AntiGnRH antibodies can induce castrate levels of testosterone in patients with advanced prostate cancer. British J Cancer 2000; 83(4): 443-446.

31. Yu L, Zhang ZF, Jing CX, Wu FL. Intraperitoneal administration of gonadotropin-releasing hormone-PE40 induces castration in male rats. World J Gastroenterol 2008; 14(13): 21062109.

32. Amory JK, Page ST, Anawalt BD, Matsumoto AM, Bremner WJ. Acceptability of a combination testosterone gel and depomedroxyprogesterone acetate male contraceptive regimen. Contraception 2007; 75: 218-223.
33. Wu FCW. Hormonal approaches to male contraception: Approaching reality. Molecular and Cellular Endocrinology 2006; 250: 2-7.

34. Amory JK, Page ST, Bremner WJ. Drug Insight: Recent advances in male hormonal contraception. Nat Clin Prac Endocrinol Metab 2006; 2: 32-41.

35. Zhang L, Shah IH, Liu Y, Vogelsong KM, Zhang $L$. The acceptability of an injectable once-amonth male contraceptive in China. Contraception 2006; 73: 548-553.

36. Meriggiola MC, Cerpolini S, Bremner WJ Mbizvo MT, Voselsong KM, Martorana G, Pelusi G. Acceptability of an injectable male contraceptive regimen of norethisterone enanthate and testosterone undecanoate for men. Hum Reprod 2006; 21(8): 2033-2040.

37. Amory JK. Male hormonal contraceptives: current status and future prospects. Treat Endrocrinol 2005; 4(6): 333-341.

38. Amory JK. Male hormonal contraceptives. Minerva Ginecol 2006; 58(3): 215-226.

39. Amory JK. Contraceptive developments for men. Drugs Today (Barc) 2007; 43(3): 179-192.

40. Liu PY, Swerdloff RS, Wang C. Recent methodological advances in male hormonal contraception. Contraception 2010; 82: 471475.

41. Wang C, Swerdloff RS. Male hormonal contraception. American J Obst Gynecol. 2004; 190: S60-S68.

42. Meriggiola MC, Costantino A, Cerpolini S. Recent advances in hormonal male contraception. Contraception 2002; 65: 269-272.

43. Gu $Y$, Liang $X, W u W$, Liu $M$, Song $S$, Cheng $L$, Bo $L$, Xiong $C$, Wang $X$, Liu $X$, et al. Multicenter contraceptive efficacy trial of injectable testosterone undecanoate in Chinese men. $J$ Clin Endocrinol Metab 2009; 94(6): 19101915.

44. Gu YQ, Wang $X H, X u D$, Peng $L$, Cheng LF, Huang MK, Huang ZJ, Zhang GY. A multicenter contraceptive efficacy study of injectable testosterone undecanoate in healthy Chinese men. J Clin Endocrinol Metab 2003; 88(2): 562-568.

45. Von Eckardstein S, Noe G, Brache V, Nieschlag E, Croxatto H, Alvarez F, Moo-Young A, Sivin I, Kumar N, Small M, et al. A clinical trial of 7 alpha-methyl-19-nortestosterone implants for possible use as a long-acting contraceptive for men. J Clin Endocrinol Metab 2003; 88(11): 5232-5239.

46. Page ST, Amory JK, Anawalt BD, Irwig MS, Brockenbrough AT, Matsumoto AM, Bremner WJ. Testosterone gel combined with depomedroxyprogesterone acetate (DMPA) is an effective male hormonal contraceptive regimen and is not enhanced by the addition of the GnRH antagonist acyline. J Clin Endocrinol Metab 2006; 91(11): 4374-4380.

Trop J Pharm Res, December 2012;11 (6):1020 
47. Meriggiola MC, Constantino A, Saad F, D'emidio L, Morselli Labate AM, Bertaccini A, Bremner WJ, Rudolph I, Ernst M, Kirsch B, et al. Norethisterone enanthate plus testosterone undecanoate for male contraception: effects of various injection intervals on spermatogenesis, reproductive hormones, testis and prostate. $J$ Clin Endocrinol Metab 2005; 90(4): 20052014.

48. Meriggiola MC, Bremner WJ, Costantino A, Pavani $A$, Capelli M, Flamigni C. An oral regimen of cyproterone acetate and testosterone undecanoate of spermatogenic suppression in men. Fertil Steril 1997; 68(5): 844-850.

49. Meriggiola MC, Farley TM, Mbizvo MT. A review of androgen-progestin regimens for male contraception. J Androl 2003; 24(4): 466-483.

50. Gaw Gonzalo IT, Swerdloff RS, Nelson $A L$, Clevenger B, Garcia R, Berman N, Wang C. Levonorgestrel implants (Norplant II) for male contraception clinical trials: combination with transdermal and injectable testosterone. J Clin Endocrinol Metab 2002; 87(8): 3562-3572.

51. Nieschlag E, Zitzmann M, Kamischke A. Use of progestins in male contraception. Steroids 2003; 68: 965-972.

52. Kinniburgh $D$, Zhu $H$, Cheng L, Kicman AT, Baird $D T$, Anderson RA. Oral desogestrel with testosterone pellets induces consistent suppression of spermatogenesis to azoospermia in both Caucasian and Chinese men. Hum Reprod 2002; 17(6): 1490-1501.

53. Place VA. Buccal drug delivery system for use in male contraception. United States Patent No: 6180682 B1. Jan 30, 2001. [Homepage on the Internet] http://www.freepatentsonline.com/ 6180682.html Accessed 16. February, 2012.

54. Wenk M, Nieschlag E. Male contraception: $A$ realistic option? The Eur J Contracep Reproduct Health Care 2006; 11(2): 69-80. (doi: 10.1080/13625180600699548).

55. Behre HM, Kliesch S, Lemcke B, von Eckardstein $S$, Nieschlag E. Supression of spermatogenesis to azoospermia by combined administration of $\mathrm{GnRH}$ antagonist and 19 nortestosterone cannot maintained by this non-aromatizable androgen alone. Hum Reprod 2001; 16(12): 2570-2577.

56. Hoesl CE, Saad F, Pöppel M, Altwein JE. Reversible, Non-Barrier Male Contraception: Status and Prospects, European Urology 2005; 48: 712-723.

57. Nieschlag $E$, Henke $A$. Hopes for male contraception. Lancet 2005; 365: 554-555.

Trop J Pharm Res, December 2012;11 (6):1021 